TITLE:

\title{
The Polarized Absorption Edge and the Davydov Splitting of Anthracene(Abstract_要旨)
}

$\operatorname{AUTHOR}(S)$ :

Matsui, Atsuo

\section{CITATION:}

Matsui, Atsuo. The Polarized Absorption Edge and the Davydov Splitting of Anthracene. 京 都大学, 1967, 理学博士

\section{ISSUE DATE:}

1967-01-23

URL:

http://hdl.handle.net/2433/212095

RIGHT: 


\section{【56】}

氏 名

学位の種類 学位記 番 号 学位授与の日付 学位授与の要件 学位論文題目

諭交調查委員
松 井 敦 男
まつ

理学 博士

論 理 博 第 170 号

昭 和 42 年 1 月 23 日

学 位規則第 5 条第 2 項該当

The Polarized Absorption Edge and the Davydov Splitting of Anthracene

(アンスラセン結晶の吸収端とダビドフ分裂)

(主 査)

教 授查田洋一教授高橋勲 教授富田和久

\section{論文内容 の 要旨}

主論文は, 有機結晶中の $\pi$ 電子による電気伝導や光伝導に関連してアンスラセン結晶の励起状態の知 見をうる目的でその吸収スペクトルを研究したものである。

著者はまずアンスラセン精製の過程を検討し，不純物として除却の最も困難なテトラセンの偏析係数を 螢光法によって求め, その結果を利用して有効な带域精製の条件を決定し，てれにより現在のとてろ最高 純度のアンスラセンの単結晶を育成した。アンスラセンの結晶は単斜晶系に属し, 単位格子内に並進操作 では互に重放合わすことのできない 2 種のアンスラセン分子が存在することが知られている。著者は，乙 の結晶についてその $a$ 軸扔よび $b$ 軸に沿った偏光による近紫外吸収を測定し，とくにその長波長端の構造 を詳しくしらべた。

この領域に現われる吸収スペクトルは分子内の遷移 $A_{1 g} \rightarrow B_{2 u}$ によるもので分子内振動に付随した振動 構造を有する。各振動帯はいずれもダビドフ分裂を示すが, 最も短波長側の $0 \rightarrow 0$ 帯がダビドフ分裂大き く, 吸收端との関連性を知る上で重要である。著者は分裂した成分を光の偏光方向と対応させ添字 $a$ およ び $b$ で区別し，吸収湘定を $79 \sim 390^{\circ} \mathrm{K}$ の範囲で行なった。

結果として，第 1 吸収帯の長波長端の吸収係数は

$$
\kappa=\kappa_{0} \exp \left(-\sigma \frac{E-E_{0}}{k T}\right)
$$

で表わせることが明らかになった。との式は, Urbach 法則を示すあのである。式中，Eは入射光の光量 子エネルギー， $\kappa_{0}$ は $E=E_{0}$ に拈ける吸収係数，。は steepness パラメーターである。これらの諸量は いずれも偏光 $a$ および $b$ に対応して2成分に分かれている。Urbach 法則により，収斂位置 $E_{0 a}, E_{0 b}$ は $0 \rightarrow 0$ 帯の吸収の山の位置とほほ一致した。また。steepness パラメーター $\sigma_{a}, \sigma_{b}$ はすべての温度にわ たり,たがいに等しく, $293^{\circ} \mathrm{K}$ 以上では殆ど常数となった。つぎに, $\sigma$ の温度変化を解析し, 吸収の長波 長側尾端の形がアンスラセン分子の分子内振動により決定されることを明らかにした。また, Urbach 法 
則は第 1 吸收帯に接続する，第 1 吸収肩に拈いても成立しているてとがわかったが，肩の温度依存性より 著者は, この肩が振動遷移 $1 \rightarrow 0$ を伴った電子帯であるととを明らかにしている。この吸収肩の長波長側 飞第 2 の肩が認められるが，との肩での Urbach 法則を考虑すれば，乙の肩は $2 \rightarrow 0$ の振動準位間遷移 であることが示された。

著者によれば，第 1 吸収帯の山の各成分， $E_{\boldsymbol{a}}$ と $E_{b}$ 間の距離，即ち，ダビドフ分裂の大きさは偏光の $b$ 軸に対する方位の狂いに対し，極めて敏感である。また，温度の変化に対しては， $b$ 成分の変位が $a$ 成 分に比し遙加大きく, $a, b$ の間隔は室温で $190 \mathrm{~cm}^{-1}$, 液体窒素温度で $265 \mathrm{~cm}^{-1}$ となった。乙の大き さの変化 $75 \mathrm{~cm}^{-1}$ は冷却による分子間隔の減少, または, 分子方位の変化による増加 $\left(\sim 6 \mathrm{~cm}^{-1}\right)$ に比 し著しく大きい。ここに扔いて著者は, 温度による間嵒の変化の主要原因を格子内における分子の科動 (libration) と考えた。実際，X線分析によれば, アンスラセン分子の短軸のまわりの科動振幅は室温で $2.7^{\circ}, 95^{\circ} \mathrm{K}$ 温度で0.9゚である。この差が $b$ 軸の狂いに相当するとすれば, 分裂の温度変化は $70 \mathrm{~cm}^{-1}$ となり, 分裂の変化の実測值と一致する。乙のように著者は, ダビドフ分裂の大きさは, 分子軸の科動や てれに同等な結晶格子の不整によって大きく影響されると結論し, 最後に吸収の偏光比とダビドフ分裂の 関係，不純物として混入せるテトラセンの濃度とダビドフ分裂の関係をしらべるてとによって，ての結論 を一層確かめている。

参考論文 1 は弗化リチウムの反射スペクトルを測定し, 吸収測定が困難な第 1 励起子帯の山の位置と乙 の帯の振動子強度を求めようとするものである。反射率は $12 . \mathrm{eV} て ゙$ て最大であった。参考論文 2 は, 注意 深く合成した塩化カリウムに混入させた沃化カリウムが塩化カリウムの吸収端に示す構造について報告し ている。参考論文 3 は, アンスラセン中に不純物として存在するテトラセンを螢光法で $10^{-6}$ モル濃度まで 定量できるととを示し，その定量法を用いて，アンスラセンに対するテトラセンの偏析係数を 0.1 と求め た。参考論文 4 は, アンスラセン単結晶の反射スペクトルを偏光により測定した結果, 吸収測定では不明 確であった第 2 吸収領域での構造を明らかにした。

\section{論文審査の結果の要旨}

有機結晶の電導性や光伝導性の研究は急速な進展を示しているが複雑なその機構の解明にはまだはど遠 い。乙の研究の目的はアンスラセン結晶が光吸収の後で, 結晶内に発生する電荷の担体の本性を明らかに するため，その吸収スペクトルを解析することである。アンスラセン結晶の各吸収帯はその結晶構造上， 必然的にダビドフ分裂を示す筈である。アンスラセン分子間力の特性はダビドフ分裂ならびにその偏光 比の大さに直接反映するので, 著者はとくにてれらの量に関心を払って解析を行なった。即ちダビドフ分 裂を考慮した詳細な解析の結果, アンスラセンの近紫外領域の吸収の長波長端の吸収係数の温度低存性が Urbach 法則によって表わされるととが明らかになり，吸収端に現われる構造は分子内振動との関連によ って説明された。

ダビド分裂は比較的新らしく注目をうける現象である。とくにアンスラセンの場合, 従来分裂の大き さが観測ごとに変動し，その原因が不明であった。著者は自山の開発した带域溶融法で製作し，現時点で は最純の結晶を用いてダビドフ分裂の温度㧍よびテトラセン不純物の濃度依存性を研究するととにより, 
この原因が主として分子の格子点を定点とする熱的科動，あるいはこれと同等な不純物による分子軸の方 向の乱れに起因することを定量的に明らかにした。なお, この論文では各振動帯について偏光比, 絶対零 度におけるダビドフ分裂値, 吸収ピークの位置, 肩の位置, それらの吸収強度の測定条件との関係を詳細 に報告している。

以上, 著者の研究は創意に富み, 有機結晶の固体物性的な研究進歩に貢献するところが茥だ大きいと考 えられる。

よって, この論文は理学博士の学位論文として価值があるあのと認める。 